\title{
Protection of Customer Lists in California
}

THE POWER of equity to protect the employer from the unconscion-

able use of confidential information acquired in the course of busimess by an employee is frequently invoked to enjoin the solicitation of customers after the termination of employment. A strong policy underlies the willingness to intervene. Equity is solicitous where a fiduciary relation is involved. ${ }^{1}$ The time, expense and effort required to build patronage makes the customer list a valuable attribute of a going business. ${ }^{2}$ The exigencies of competition make secrecy essential. ${ }^{3}$

Balanced against these considerations are the competing doctrines that equity will not aid the restraint of lawful trade, ${ }^{4}$ or prejudice the rights of innocent third persons. ${ }^{5}$ There is the feeling that experience gamed by an employee is a legitimate part of his remuneration, a concommitant of the employment. ${ }^{6}$ Short of trade secrets, his gaims are his own and equity is reluctant to deprive him of the opportunity to pursue his calling after severing relations with his former employer. ${ }^{7}$

Occasionally the victory goes to the competing premises. ${ }^{8}$ More often it goes to the considerations favoring protection. ${ }^{9}$ Where variable social and economic factors enter, it is not surprising that the reasoning of the decisions should vary or that emphasis should change..$^{10}$

1 Empire Steam Lâundry Co. v. Lozier (1913) 165 Cal. 95, 99, 130 Pac. 1180, 1182, 44 L. R.A. (N.S.) 1159, 1163; Cax. CIv. Code \$\$ 2219, 2224.

2 Empire Steam Laundry Co. v. Lozier, supra note 1, at 97,130 Pac. at 1181, 44 L. R.A. (N.s.) at 1162; Cornish v. Dickey (1916) 172 Cal. 120, 155 Pac. 629.

3 New Method Laundry Co. v. MacCann (1916) 174 Cal. 26, 161 Pac. 990, Ann. Cas. $1918 \mathrm{C} 1022$.

4 Theodore v. Williams (1919) 44 Cal. App. 34, 185 Pac. 1014; Avocado Sales Co. v. Wyse (1932) 122 Cal. App. 627, 10 P. (2d) 485; CAL. Crv. Code $\$ \S 1673,1674$.

5 Theodore v. Williams, supra note 4.

6 See Boosing v. Dorman (1912) 148 App. Div. 824, 133 N. Y. Supp. 910.

7 Theodore v. Williams; Avocado Sales Co. v. Wyse, both supra note 4.

See Pasadena Ice Co. v. Reeder (1929) 206 Cal. 697, 703, 704, 275 Pac. 944, 947; New Method Laundry Co. v. MacCann, supra note 3, at 30, 161 Pac. at 991, 992, Ann. Cas. 1918 C at 1024; Fish, The Ethics of Trade Secrets (1907) 29 Proc. Aur. Soc. MeCr. ENG. 13; Note (1917) 30 HARv. L. Rev. 655.

8 Theodore v. Williams; Avocado Sales Co. v. Wyse, both supra note 4.

9 Empire Steam Laundry Co. v. Lozier, supra note 1; New Method Laundry Co. v. MacCann, supra note 3; Cornish v. Dickey, supra note 2; Pasadena Ice Co. v. Reeder, supra note 7; Dairy Dale Co. v. Azevedo (1931) 211 Cal. 344, 295 Pac. 10; Scavengers' Protective Ass'n v. Serv-U-Garbage Co. (1933) 218 Cal. 568, 24 P. (2d) 489; Gloria Ice Cream Co. v. Cowan (1935) 89 Cal. Dec. 228, 41 P. (2d) 340; Mackechnie Bread Co. v. Huber (1923) 60 Cal. App. 539, 213 Pac. 285.

10 Notes (1913) 1 CaLIF. L. Rev. 385; (1923) 11 ibid. 438; (1929) 18 ibid. 88;

(1919) 19 Cor. L. Rev. 233. 
I.

The earlier cases generally involved retail delivery routes. By long course of dealing, the customers reasonably could be expected to continue, and it would be a distinct loss to have such knowledge come into the hands of competitors.

Various grounds have been suggested as the basis for the protection of trade secrets, all of which have received support from the California customer hist cases. ${ }^{11}$ Irrespective of express contract, it was felt that the employer had an interest that should be protected. ${ }^{12}$ Calling it property states a conclusion rather than a reason. ${ }^{13}$ While the majority of the cases have adhered to this designation it is definitely settled that the extent of the employer's property interest is insufficient to support an action at law for damages, or be the subject of conversion. ${ }^{14}$

In the leading case of Empire Steam Laundry Co. v. Lozier, ${ }^{15}$ the contract of hiring contained an express provision that the employee would not solicit customers after the termination of the employment. The supreme court cited no prior California customer list cases but one ${ }^{16}$ yet it rejected the convenient ground of express covenant in favor of the broad equitable principle that equity will protect against unwarranted disclosure of trade secrets. The court largely relied on a series of New York cases involving the trade practices of the A. \& P. grocery chain, decided some five years previously. ${ }^{17}$ In those cases, Witkop \& Holmes, retail grocers, had built up an extensive and flourishing trade. They districted the city, maintained a carefully compiled customer hist numbering ten thousand patrons, and sent drivers over designated routes, supplying each with a list for his territory. To stinulate trade, they established their own trading stamp system, giving stamps with purchases and redeeming the full books.

11 (a) Breach of Implied Contract. Empire Steam Laundry Co. v. Lozier, supra note 1. (b) Breach of Confidence. Ibid.; Cornish v. Dickey, supra note 2; Pasadena Ice Co. v. Reeder, supra note 7; Dairy Dale Co. v. Azevedo, supra note 9. (c) Property. Empire Steam Laundry Co. v. Lozier, supra note 1; Cornish v. Dickey, supra note 2; New Method Laundry Co. v. MacCann, supra note 3; Mackechnie Bread Co. v. Huber, supra note 9.

12 Empire Steam Laundry Co. v. Lozier, supria note 1, at 99, 130 Pac. at 1182, 44 L. R.A. (N.S.) at 1163.

13 DuPont v. Masland (1917) 244 U.S. 100.

14 Olchewski v. Hudson (1927) 87 Cal. App. 282, 262 Pac. 43; Adkins v. Model Laundry (1928) 92 Cal. App. 575, 268 Pac. 939.

15 Supra note 1.

16 Gower v. Andrew (1881) 59 Cal. 119, 43 Am. Rep. 242, in which the defendant's wrongful conduct in soliciting patrons was given casual mention.

17 Witkop \& Holmes Co. v. Boyce (1908) 61 Misc. Rep. 126, 112 N. Y. Supp. 874, aff'd (1909) 131 App. Div. 922, 115 N. Y. Supp. 1150; Witkop \& Holmes v. Boyce (1909) 64 Misc. Rep. 374, 118 N. Y. Supp. 461; Witkop \& Holmes v. Great Atl. \& Pac. Tea Co. (1910) 69 Misc. Rep. 90, 124 N. Y. Supp. 956. 
The rivalry of the expanding Atlantic \& Pacific chain culminated in a policy of luring away the plaintiff's drivers, securing from them the customer lists and sending out drivers to canvass and solicit from the lists. To add to the inducements to these customers, the A. \& P. offered trading stamps of its own and exchanged them for the unredeemed portion of the Witkop \& Holmes books.

The practices clearly involved unfair competition, and on this doctrine the New York courts relied in granting relief against the former employees and against the competitor. The court was buttressed by an express statutory provision making it a misdemeanor knowingly to make use of customer lists of another without the consent of the owner, ${ }^{18}$ and by an express covenant in the contract of employment itself. The decision was rested largely on the general law of unfair competition, however, the court saying in part:

"In recent years there has been developed, by the adjudication of our courts and by legislation, a considerable body of law looking toward the protection of the business world against unfair competition, and if we correctly interpret these decisions, a court of equity stands ready to restrain such acts. We, therefore, are of the opinion that, independent of any express contract between the parties, equity will restrain the acts of which the plaintiff complains, and which the defendant threatens, and claims the right to do. This arises out of a violation of duty having its origin in the relation of employer and employed, and an implied contract that an employee will not divulge confidential knowledge gained in the course of his employment, or use such information to his employer's prejudice.'19

The Empire case quoted this language with approval. It treated the customer list as a trade secret, a property interest whicl entitles the employer to restrain the agent from its use, except for the purpose for which it was obtained. The doctrine expressed is that of trade secrets, but the court's rationale of that doctrine is unfair competition. ${ }^{20}$

In view of the postulates on which the injunction was granted, its scope is interesting. The Witkop \& Holmes cases on which the California court liad placed great reliance, granted a broad imjunction, ${ }^{21}$ but in the suit against the competitor A. \& P. stores, the court had said:

"The defendant tea company undoubtedly has the right to solicit the trade of plaintiff's customers, and to obtain a list thereof by using opportunities for observation open to all. Plamtiff had no vested property rights in the trade of such customers." 22

The Empire case went farther and enjoined not only the solicitation, but forbade the defendant from receiving laundry froin plaintiff's cus-

18 N. Y. Penal Code $\$ 642$.

19 Witkop \& Holmes Co. v. Boyce (1908) 61 Misc. Rep. 126, 132, 112 N. Y. Supp. 874,878 .

20 Note (1913) 44 L. R. A. (N.s.) 1159.

21 Cases supra note 17.

20 Witkop \& Holmes Co. v. Great Atl. \& Pac. Tea Co., supra note 17, at 92, 124 N. Y. Supp. at 958. 
tomers. ${ }^{23}$ The court penalized not only the guilty employee, but those patrons who might have preferred the work of the defendant to that of the plaintiff.

What led to this drastic injunction? There is no hint of large scale conspiracy as was present in the Witkop \& Holmes cases where the ruthless practices would have been a better ground for such a drastic remedy. The Empire case was the ordinary situation of a former employee who is guilty of bad faith.

Three years later the court had occasion to reconsider the problem in New Method Laundry Co. v. MacCann. ${ }^{24}$ The trial court had refused to enjoin the employee from receiving business from customers on the list, and on appeal this was claimed as error. The supreme court refused to overturn the holding of the trial court.

"The employee's conduct [in the Empire case] under the facts shown clearly constituted an unconscionable and unwarranted use of trade secrets belonging to his former employer as well as violation of the contract he had entered into." 25

Clearly, then, something depended on the normative feature of the employee's conduct. It is more than the secret that is being protected. The method of using the information is a cogent force in the extent to which relief is withheld or granted.

The application of unfair competition to the doctrine of trade secrets received further support in the case of Pasadena Ice Co. v. Reeder.20 The defendant, and others who had acquired confidential information in plaintiff's office, quit the employ and began a competing business under the ironic name of Purity Ice Company. Other former employees gravitated to the Purity banner, buying from the Purity Company and distributing in their own trucks to customers of plaintiff whose business they solicited. The court held that this involved improper use of business secrets through a method of unfair competition. This unfair competition consists in the detrimental use by the employee of information gained in the course of the employment concerning those secrets, and,

"It is the wrongful use of the employee of the business secrets of the employer which the courts have held constitutes the injury to the employer."27

II.

The cases considered to this point have involved retail routes. Sup. pose, instead, the customers are wholesale buyers whose names appear

23 (1913) 1 CaIIF. L. Rev. 385.

24 Supra note 3.

25 New Method Laundry Co. v. MacCann, supra note 3, at 34, 161 Pac. at 993, Ann. Cas. $1918 \mathrm{C}$ at 1025.

26 Supra note 7.

27 Pasadena Ice Co. v. Reeder, supra note 7, at 703, 275 Pac. at 947. See Notes (1911) 31 L. R.A. (N.S.) 249; (1912) 35 L.'R.A. (N.s.) 119. 
in directories and who are few enough in number to afford competitors an easy way of discoverimg for themselves who the customers are? In 1932 this problem came before the district court of appeal, and the difference in degree determined the result. ${ }^{28}$

Plaintiffs were dealers in avocados and employed defendants on a commission basis in a designated territory. Sales were made to stores, fruit stands, clubs and hotels. Defendants quit the employ of plaintiff and entered that of defendant, Wyse, and proceeded to canvass over the same neighborhood. The trial court found that none of the information was of a confidential or secret nature, that the identity of these customers could be ascertained by anyone, and that they did not buy exclusively from plaintiff. An injunction was denied on the basis of the findings. On appeal, the judgment was affirmed on the ground that no trade secret was involved. The court said:

"In all of the California cases in which the injunction has been granted, the customers were individuals being ultimate consumers of commodities, or individual customers of laundry, bread, ice or milk concerns, and the hists of names and addresses were secret lists; but can a list of grocery stores, vegetable or fruit stands, etc., where avocados are sold to the general public, where displays are made to attract the attention, be considered as anyone's private list? Can it constitute confidential information and a trade secret?"29

The court reviewed and distinguished the prior California cases and held this to be analogous to the New York case of Boosing v. Dorman. As the Avocado case distinguished the exclusive patronage of retail customers from the non-exclusive patronage of wholesale customers, so the New York decision had distinguished the Witkop \& Holmes disputes. Refusing to apply the trade secrets cases to a situation where anyone might discover who the customers are, the New York court concluded that the facts indicated no unfair trade practices, and that a different result should follow:

"The employee leaving an employer's service cannot leave the experience or knowledge there acquired, and saving the matter of trade secrets, already mentioned, these are legitimate additions to her personal equipinent, which she has a perfect right to use for her own benefit."30

The Avocado case likewise adverts to the trade practices disclosed. While defendant Wyse stamped his fruit with the same size print, the same color ink, and used the same size boxes, the court found that he did not deceive customers, or intend to deceive them into believing that they were buying the plaintiff's product. This is the traditional language of unfair competition. ${ }^{31}$ Throughout the case it is apparent that the

\footnotetext{
${ }^{2 S}$ Avocado Sales Co. v. Wyse, supra note 4.

29 Ibid. at 633,10 P. (2d) at 488.

30 Boosing v. Dorman, supra note 6, at 827, 133 N. Y. Supp. at 912 .

31 The "Passing Off" doctrine. See American Washboard Co. v. Saginaw (C. C. A. 6th, 1900) 103 Fed. 281; Crescent Tool Co. v. Kilborn \& Bisbop Co. (C.C.A. 2d, 1917) 247 Fed. 299.
} 
judges' favorable opinion of the business ethics of defendants influenced the unwillingness to grant an injunction..$^{32}$

The refusal of the district court of appeal to issue an injunction that would prevent all dealings with the customers of previous employers finds support in other cases. ${ }^{33}$ In a decision not cited by the Avocado case, ${ }^{34}$ the same court has refused to hold an employee guilty of contempt resulting froin advertismg his new connection. The injunction granted had restrained soliciting or receiving from the customers so solicited. $\mathrm{He}$ inserted an advertisement in a newspaper, stating that he was agent for the competitor, and placed his name on the competitor's delivery wagon. To the contention of plaintiff that this amounted to contempt, the court replied:

"To so hold would deprive him of the right to pursue a lawful calling as a means of obtaining a livelihood. This in the absence of positive covenant may not be done."35

Theodore $v$. Williams likewise gave weight to considerations favoring the privilege of the customers to change their patronage. The rights of third parties innocent of inequitable conduct are involved. ${ }^{36}$ The constitutional guarantees of liberty include the privilege of choosing the persons with whom they wish to deal. While the Avocado case placed no stress on this feature, it did deny the right of the employer to appropriate an exclusive access to buyers through advertising and the creation of an appetite for his wares. ${ }^{37}$

The Avocado case represents a victory for the competing policy of free competition. Unless some violation of fiduciary relation is definitely in issue, there is no equitable principle warranting the use of the injunction as an economic lever against the enterprise of former employees. ${ }^{38}$ The mere fact that the establishment of his business required effort and expense does not of itself entitle the employer to the shield of a legal monopoly. ${ }^{39}$

III.

If the relief granted in the retail route cases is predicated on unconscionable use of busmess secrets, and the denial of relief in the Avocado case is based on the lack of secrecy, what considerations can

32 Avocado Sales Co. v. Wyse, supra note 4, at 634, 635, 10 P. (2d) at 488.

33 Theodore v. Williams, supra note 4; see New Method Laundry Co. v. MacCann, supra note 3, at 36, 161 Pac. at 993, Ann. Cas. $1918 \mathrm{C}$ at 1026.

34 Theodore v. Williams, supra note 4 ; (1923) 11 CAxIF. L. REv. 438.

35 Theodore v. Williams, supra note 4, at 37, 38, 185 Pac. at 1015.

$36 \mathrm{New}$ Method Laundry Co. v. MacCann, supra note 3, at 32, 161 Pac. at 992, Ann. Cas. $1918 \mathrm{C}$ at 1024.

37 Avocado Sales Co. v. Wyse, supra note 4, at 634, 635, 10 P. (2d) at 488, 489.

$38 \mathrm{Di}$ Angeles v. Scauzillo (Mass. 1934) 191 N. E. 426; see Hines, Employees' Covenants Not to Solicit Former Patrons (1932) 20 CALIF. L. REv. 607.

39 Avocado Sales Co. v. Wyse, supra note 4. 
be expected to motivate a court in favor of intervention where the customer list is relatively public?

The case of Scavengers' Protective Association v. Serv-U-Garbage Co..$^{40}$ made it apparent that the line of demarcation is by no means fixed. Defendants started a competing corporation and defended their activity in soliciting the patronage of customers of their former employer on the grounds that no confidential information was used. A city ordinance fixed rates and required everyone to secure scavenger service. In the district involved in the dispute, most of the persons were served by plaintiff, hence the identity of the customers might easily be ascertained by anyone. Plaintiff pointed out, however, that the salvage value of waste paper and junk is an important item of the business. Lower rates and bonuses go to those wlose refuse lias a salvage value, and records of it are kept.

The evidence disclosed that defendants had used this information to underbid their former employers. The supreme court in bank approved the injunction, holding that this element made the information a trade secret, and that the practices of defendants constituted improper use of confidential information and amounted to unfair competition.

The list of customers, not necessarily secret in itself, might, then, be made a trade secret if there is confidential information concerming the value of these customers. A showing of this factor takes the case out of the doctrine of Avocado Sales Co. v. Wyse, ${ }_{3}^{41}$ and brings it within the rule of Pasadena Ice Co. v. Reeder. ${ }^{42}$

Two years before this decision, the court lad upheld the injunction granted in Dairy Dale Co. v. Azevedo.43 The defendant had appealed on the grounds of absence of secrecy, in that plaintiffs serve nearly onelialf of the residents where the routes in question are located. The court disposing of this contention, said:

"There is no merit in this assertion since obviously it is not merely the knowledge of the identity of the customers, but the friendly contact with them which is important to the solicitors ... 'they became personally acquainted with the customers of the respondent, their respective places of residence, their peculiar likes and fancies and other characteristics, a knowledge of which would greatly aid them in securing and retaining the business of such former customers.' "44

The case of Gloria Ice Cream Co. v. Cowan ${ }^{45}$ definitely establishes the willingness of the court to uphold injunctions even where no secrecy

40 Supra note 9.

41 Supra note 4.

42 Supra note 7.

43 Supra note 9.

44 Ibid. at 345, 295 Pac. at 10, citing Pasadena Ice. Co. v. Reeder, supra note 7.

45 Supra note 9. 
is present. Its basic doctrine is not new. It was foreshadowed by the Empire case and by the consistent growth of the law of unfair competition in this field, but the application of unfair competition to this situation is far reaching.

As did its predecessors, the Gloria case presented a delivery route, a dissatisfied employee and an avaricious competitor. Like the Avocado case, however, the route was not retail, but wholesale, and called for dehivery to restaurants, bakeries, grocery stores, markets and similar concerns. The court conceded that these did not constitute trade secrets, since the public and any competitor might investigate for himself. The trial court had denied an injunction on this ground, even though it thought reprehensible the conduct of the defendant employee in aiding the competitor to lure away these customers from plaintiff. This disapprobation assumed greater significance in the supreme court where the conduct of the defendant was made decisive of the issue. The element of intent to injure the plaintiff's business constituted unfair tactics warranting the granting of the injunction, and the lower court was reversed.

The defendant relied on the Avocado case as establishing the right of an enployee to solicit the patrons of his former employer where no trade secrets are present. The court approved Avocado Sales Co. v. Wyse but said that the case at bar differed from it, since the acts in this case were done in.carrying out a preconceived plan to injure the business of the planitiff over a well-established trade route, and that equity will not tolerate such unfair trade tactics. ${ }^{46}$ The rule applicable to this situation, the court held, is that of Empire Steam Laundry Co. v. Lozier, Pasadena Ice Co. v. Reeder and Dairy Dale Co. v. Azevedo, and not that of Avocado Sales Co. v. Wyse. Disapprobation of business practices outweighed all those considerations which in the past have led to the denial of injunctive relief in the absence of secrecy.

\section{IV.}

Analytically, the Cahifornia cases fall into three groups:

(a) The usual case of the retail delivery route where the knowledge constitutes a trade secret and is protected as such. ${ }^{47}$

(b) Those cases where the element of secrecy of the cnstoiners' identity is either absent or ininimized, but where rehef is granted on doctrines of unfair competition. ${ }^{48}$

46 Ibid. at 230,41 P. (2d) at 342 .

47 Empire Steam Laundry Co. v. Lozier, supra note 1; Cornish v. Dickey, supra note 2; New Method Laundry Co. v. MacCann, supre note 3 ; Pasadena Ice Co. v. Reeder, supra note 7; Mackechnie Bread Co. v. Huber, supra note 9.

48 Dairy Dale Co. v. Azevedo; Scavengers' Protective Ass'n v. Serv-U-Garbage Co.; Gloria Ice Cream Co. v. Cowan, all supra note 9. 
(c) The intermediate case where there is no secrecy and no unfair competition and where relief is denied. ${ }^{49}$

Given a situation indicating a customer list unknown to competitors or not easily discoverable, an injunction may be expected to issue on the basis of trade secrets, if such secrets are abused by a method of unfair competition. ${ }^{50}$ Given a situation where the list is public, but add to it confidential information concerning those customers and the value of their business, or facts indicating a willful attempt to injure the business of the former employer, an injunction may issue..$^{51}$

The implications of the cases in the second group leave hittle practical force to Avocado Sales Co. v. Wyse and its salutary curb on the use of the injunction against former employees. In a realistic jurisprudence it can hardly be expected that an astute advocate representing the employer will overlook those implications.

OAKLANd, CaItFornta.

Bauer Edwin Kramer.

\footnotetext{
49 Avocado Sales Co. v. Wyse, supra note 4.

50 Cases supra note 47.

51 Cases supra note 48.
} 